\title{
Composition and antimicrobial activity of two Capsicum
}

extracts

\author{
Combinación de dos extractos de Capsicum: composición y actividad \\ antimicrobiana \\ Combinação de dois extratos de Capsicum: Composição e atividade \\ antimicrobiana
}

Teresa Gladys Cerón Carrillo Benemérita Universidad Autónoma de Puebla, México tgceronc_10@hotmail.com Norma Angélica Santiesteban- López Benemérita Universidad Autónoma de Puebla, México asantiesteban2@hotmail.com

Ramón Sebastián Acle Mena

Benemérita Universidad Autónoma de Puebla, México raclemx@yahoo.com.mx

\section{Resumen}

Las bacterias patógenas son responsables de la mayoría de las epidemias alimentarias. Las bacterias se han vuelto cada vez más resistentes a los antibióticos a través de los años y ahora, se deben de considerar agentes nuevos y naturales para controlarlas. Los extractos de chile fueron obtenidos, secando, cortando y separando las diferentes partes de la fruta y colocándolos en sistema Soxhlet para su extracción con etanol. Se llevó a cabo la evaluación de su composición, la capacidad antioxidante y la evaluación de las concentraciones inhibitorias de la mezcla de los extractos de chile Serrano y Habanero contra Escherichia coli y Listeria monocytogenes. La ruta del chile habanero completa demostró tener el mayor contenido de capsaicinoides. La fruta completa de chile Serrano tuvo el mayor contenido de compuestos fenólicos y la mayor cantidad de flavonoides por sobre los demás extractos. Las semillas de Habanero demostraron tener la mayor capacidad antioxidante. Se observó que la fruta completa del chile Habanero y las semillas del mismo tienen el menor efecto 
inhibitorio contra E. coli y L. monocytoegenes respectivamente. Se observó también efectos sinérgicos y aditivos cuando se combinaban los extractos en contra de ambas bacterias, lo que significó que se presente un mayor efecto antimicrobiano cuando se combinan los extractos que cuando se aplican individualmente. El efecto antimicrobiano depende de la especie de chile.

Palabras clave: Capsicumm annuum, Capsicum chinense concentración mínima inhibitoria, índice de concentración fraccional inhibitoria, fitoquímicos.

\section{Abstract}

Pathogenic bacteria, are responsible for most of the foodborne outbreaks. Bacteria became more resistant to antiobiotics throughout years and, nowadays, new and natural agents most be considered for controlling them. Pepper extracts were obtained by drying, cutting, and separating the different parts of the fruit and placing them into a Soxhlet system for further extraction with methanol. Evaluation of the composition, antioxidant activity, and inhibitory concentrations of a blend of Serrano and Habanero pepper extracts against Escherichia coli and Listeria monocytogenes was studied. Habanero whole fruit had the highest capsaicinoid content. Serrano whole fruit had the highest phenolic content and the most flavonoids of all extracts. Habanero seed had the highest antioxidant activity. It was observed that the Habanero whole fruit and its seeds had the lowest minimum inhibitory concentrations of $E$. coli and L. monocytogenes, respectively. It was also observed that there were synergistic and additive effects when extracts were combined against both bacteria; meaning that there is an increased antimicrobial effect when combined than when each extract was applied individually. The antimicrobial effect depends on the pepper species.

Key words: Capsicum annuum, Capsicum chinense, minimal inhibitory concentration, fractional inhibitory concentration index, phytochemicals. 


\section{Resumo}

As bactérias patogénicas são responsáveis pela maioria das epidemias de alimentos. As bactérias têm se tornado cada vez mais resistentes aos antibióticos ao longo dos anos e agora devem ser considerados agentes novos e naturais para controlá-los. Os extractos foram obtidos de pimentão, secagem, corte e separação das diferentes partes do fruto e colocando no sistema de extracção de Soxhlet de etanol. avaliação da sua composição, foi realizada a capacidade antioxidante e de avaliação de concentrações inibitórias da mistura de extractos de pimentão e Serrano Habanero contra Escherichia coli e Listeria monocytogenes. O habanero rota completa provou ter o maior teor de capsaicinoids. O fruto cheio de Serrano Chile teve o maior teor de compostos fenólicos e flavonóides como muito acima dos outros extratos. sementes Habanero provou ter a maior capacidade antioxidante. Observou-se que a fruta e sementes completa habanero da mesma têm o efeito inibitório menos contra E. coli e L. monocytoegenes respectivamente. efeitos sinérgicos e aditivos também foram observados quando combinado extratos contra ambas as bactérias, o que significava que apresentam um maior efeito antimicrobiano quando os extratos quando aplicado combinados individualmente. $\mathrm{O}$ efeito antimicrobiano depende das espécies de pimentão.

Palavras-chave: Capsicumm annuum, concentração inibitória mínima Capsicum chinense, fracionário índice de concentração inibitória, fitoquímicos.

Practical Applications: the use of natural antimicrobial products against two well-known pathogenic bacteria with the advantage of its antioxidant properties and its pungent flavor.

Fecha recepción: Enero 2016

Fecha aceptación: Junio 2016

\section{Introduction}

Pathogenic bacteria, such as Escherichia coli and Listeria monocytogenes are very important to the food industry. They cause a significant number of gastric diseases worldwide every year (Centers for Disease Control and Prevention, 2013).

Escherichia coli is a Gram-negative, facultative anaerobic, rod-shaped bacterium found commonly in animal intestines (Pillai et al., 2005). Most strains of this specific kind of bacteria are harmless; however, some strains like O157:H7 may cause enterohemorrhagic 
illness (Buchanan and Doyle, 1997). It can be found, among others, in beef, beef products, fermented sausages, raw vegetables, apples, and orange juice (Buchanan and Doyle, 1997; Pillai et al., 2005). Listeria monocytogenes is a Gram-positive, non-sporulating rod and ubiquious bacterium responsible for human listeriosis (Farber and Peterkin, 1991). Listeriosis is a foodborne disease with a 20 to $30 \%$ mortality rate. It is considered rare and only a serious disease when found in people with a weakened immune system, such as pregnant women and the elderly.

Today, consumer safety has acquired more importance due to major pathogenic bacteria foodborne outbreaks. In 2012, over 25 people were infected with Listeria monocytogenes from contaminated cheese products in the U.S; in the same year, approximately 33 people were hospitalized for Escherichia coli O157:H7 strain infection due to consumption of prepackaged leafy greens. Finally, in 2013, another outbreak of Escherichia coli $\mathrm{O} 157: \mathrm{H} 7$ in 19 states was due to contaminated frozen products (CDC, 2013).

The growing use of antibiotics has caused constant bacteria strain mutation and hence antibiotic resistance has been observed more and more throughout the years (Marinova et al., 2005).

Several plant species have been studied due to their effects against foodborne bacteria; therefore, plant extracts mixtures, and their combination with antimicrobials are recommended to inhibit growth of foodborne pathogenic bacteria. Synergic effects are observed when plant methanolic extracts are combined with antiobiotics against several bacterial strains.

Capsicum species possess bioactive compounds that have anti-oxidant, anticancerogenic, cardiovascular assistance, antiinflamatory and even as antimicrobial properties (Cichewicz and Thorpe, 1996). Research work about the combination of Capsicum phytochemicals by Acero-Ortega et al (2003) pointed out the synergy between isolated compounds from Capsicum annuum and Capsicum chinense.

The main objective of this work is to show the composition, antioxidant activity and antimicrobial effect of all six extracts under evaluation, and to obtain the Fractional Inhibitory Concentration index of nine permutations between extracts obtained from Capsicum's seeds, pericarp and, the whole fruit (Capsicum annum L. acuminatum and 
Capsicum chinense) against Escherichia coli and Listeria monocytogenes by the checkerboard method.

\section{Materials and methods}

Two species of Capsicum fruits, Habanero pepper (Capsicum chinense) and Serrano pepper (Capsicum annumm L. acuminatum), were purchased from a local market of Puebla, Mexico.

The seeds and flesh (placenta included) were separated and placed in a food dehydrator (Excalibur, 4900, USA) at $65^{\circ} \mathrm{C}$ for $48 \mathrm{~h}$ and with an air flow of $2 \mathrm{~m} / \mathrm{s}$ until $95 \%$ water content was removed; the dried material was stored in plastic bags at room temperature.

\section{Extract preparation}

Methanol (Merck, Mexico) was used as solvent to obtain extracts. Whole pepper, seeds and pericarp extracts were prepared with the method used by Dorantes et al (2000). The dried matter $(3 \mathrm{~g})$ was put in a flask with $70 \mathrm{~mL}$ of methanol and refluxed for $3 \mathrm{~h}$. The mix was filtered through a No. 4 Whatman filter paper and subsequently added $15 \%(\mathrm{w} / \mathrm{w})$ of activated carbon and filtered again. The solvent was evaporated and re-captured by simple distillation. Finally, the extracts were stored at $-4^{\circ} \mathrm{C}$ until used.

\section{Capsaicinoids quantification}

Capsaicinoids determination was made using the method proposed by Gibbs y O’Garro (2004) in which capsaicin was quantified by spectrophotometry of yellow colored reaction. One milliliter of distilled water was added to $100 \mu \mathrm{L}$ of methanolic extract. A 0.5 $\mathrm{M}$ solution of $\mathrm{HCl}(2 \mathrm{~mL})$ was added to the extract solution and immediately added $1 \mathrm{~mL}$ of a solution containing $0.5 \mathrm{M}$ of $\mathrm{NaNO}_{2}$ (Omnichem, Mexico) and $0.025 \mathrm{M}$ of $\mathrm{NaMoO}_{4}$ (Omnichem, Mexico). After 15 min, a 0.1 M solution of $\mathrm{NaOH}$ (RBM, Mexico) was added and mixed. Absorbance was measured after $30 \mathrm{~min}$ at $430 \mathrm{~nm}$ with an UV-Visible spectrophotometer (UNICO, model 2800H USA). The curve was made with vanillin solution at the following concentrations $0.2,0.4,0.5,1.0,2.0,3.0$ and $4.0 \mathrm{mg}$ vanillin $100 \mathrm{~mL}^{-1}$ and used as a derivate of capsaicinoids. 


\section{Total Phenolic Compounds Determination}

To determine total phenolic compounds, the method proposed by Ornelas-Paz et al. (2010) was employed. Half milliliter of 50\% of Folin-Ciocalteu reagent (Sigma, Mexico) along with $8.5 \mathrm{~mL}$ of deionized water was added to $1 \mathrm{~mL}$ of the extract. The solution was incubated at room temperature for $10 \mathrm{~min}$, and then mixed with $1.5 \mathrm{ml}$ of $20 \%$ of sodium carbonate (Omnichem, Mexico) solution. The solution was incubated again at room temperature for $60 \mathrm{~min}$. Absorbance readings were made at $750 \mathrm{~nm}$ with an UV-Visible Spectrofotometer using Gallic acid as a standard reference. Total phenolic content was expressed as gallic acid equivalents (mg g.a./L extract) and a five point calibration curve (20-100 $\left.\mathrm{mg} \mathrm{L}^{-1}\right)$ was made.

\section{Antioxidant Capacity Determination}

The method to determine antioxidant capacity used was the one proposed by Re et al (1999). ABTS+ (2,2'-azinobis-(3-ethylbenzothiazoline-6 sulfonic acid)) (Sigma Aldrich, St. Louis, E.U.) radical was formed by reacting $7 \mathrm{mM}$ of ABTS+ radical with $2.45 \mathrm{mM}$ of potassium persulfate and let stand at room temperature and in the dark for 12-16 h. Then, the solution was mixed with water and $95 \%$ ethanol (1:1), until an absorbance of $0.7(+0.02)$ at $734 \mathrm{~nm}$ in a UV-Visible spectrophotometer. Extract $(20 \mu \mathrm{L})$ was added and mixed with 6 $\mathrm{mL}$ of ABTS+ solution. The measurements were made at the beginning of the reaction and after $1 \mathrm{~min}$. and the \% inhibition (equation 1) was calculated.

$\mathrm{I}(\%)=\mathrm{A}_{\mathrm{i}}-\mathrm{A}_{\mathrm{f}} / \mathrm{A}_{\mathrm{i}}$

Standard curve was made using Trolox (6-hydroxy-2,5,7,8-tetramethylchroman-2carboxylic acid) $(0.0125,0.025,0.0375,0.05,0.0625,0.125,0.15$, and $0.175 \mathrm{mg}$ Trolox $\left.\mathrm{mL}^{-1}\right)$ (Sigma Aldrich, St. Louis, MO, USA).

\section{Carotenoids determination}

To determine carotenoids in each extracts the method used by Aminifard et al (2012). A solution of acetone-hexane in a 4:6 ratio $(16 \mathrm{~mL})$ was added to a $1.0 \mathrm{~g}$ of pepper in a test tube. After homogenization, two phases were obtained and the upper phase was used for measurements at 663, 645, 505 and $453 \mathrm{~nm}$ in a UV-Vis spectrophotometer. 
Lycopene and $\beta$-carotene were calculated using the equation 2 and 3 (Nagata \& Yamashita, 1992).

Lycopene $(\mathrm{mg} / 100 \mathrm{~mL}$ of extract $)=-0.0458 * \mathrm{~A}_{663}+0.204 * \mathrm{~A}_{645}+0.372 * \mathrm{~A}_{505}-0.0808 * \mathrm{~A}_{453}$ (2)

B-carotene $(\mathrm{mg} / 100 \mathrm{~mL}$ of extract $)=0.216 * \mathrm{~A}_{663}-1.22 * \mathrm{~A}_{645}-0.304 * \mathrm{~A}_{505}+0.452 * \mathrm{~A}_{453}$

\section{Red and Yellow fractions determination}

Also, Red and Yellow fractions were determined using the method proposed by Hornero-Méndez \& Mínguez-Mosquera (2001). Pepper samples (1 g) were extracted until exhaustion of color with $50 \mathrm{~mL}$ of acetone each time; sodium chloride (10\%) solution was added to ensure phase separation; the solution was then filtered and transferred to a volumetric flask and made up to $100 \mathrm{~mL}$. Readings were made using a UV-Vis spectrophotometer at 508 and $472 \mathrm{~nm}$. Equations 4 and 5 were used to calculate red (content of capsanthin, capsorubin, $\beta$-cryptoxanthin, zeaxanthin and $\beta$-carotene) and yellow fractions (lutein and $\alpha$-carotene) (CR and CY respectively).

$$
\begin{aligned}
& \mathrm{C}^{\mathrm{R}}(\mu \mathrm{g} / \mathrm{Ml})=\left(\mathrm{A}_{508} \mathrm{X} * 2144.0-\mathrm{A}_{472} \mathrm{X} * 403.3\right) / 270.9 \\
& \mathrm{C}^{\mathrm{Y}}(\mu \mathrm{g} / \mathrm{Ml})=\left(\mathrm{A}_{472} \mathrm{X} * 1724.3-\mathrm{A}_{508} \mathrm{X}^{* 2450.1}\right) / 270.9
\end{aligned}
$$

\section{Total flavonoid content}

Flavonoid content in pepper was determined using aluminum chloride colorimetric method employed by Yoo et al (2008). One milliliter of the extract was mixed with $4 \mathrm{~mL}$ of distilled water. Then $0.3 \mathrm{~mL}$ of a $5 \%$ solution of $\mathrm{NaNO}_{3}$ was added. After 5 minutes, the resultant solution was mixed with $0.6 \mathrm{~mL}$ of a $10 \%$ solution of $\mathrm{AlCl}_{3}$. Sodium hydroxide $(1 \mathrm{M})$ solution $(2 \mathrm{~mL})$ and $2.1 \mathrm{~mL}$ of distilled water were added. Absorbance at 510 was read. Quercetin was used as a standard and results were expressed as mg quercetin equivalents $\mathrm{Kg}^{-1}$ of dry weight. Quercetin calibration was made by preparing quercetin $(0.2$ a $2.0 \mathrm{mg}$ $\mathrm{mL}^{-1}$ ) in methanol. 


\section{Strains and growth conditions}

Escherichia coli (ATCC 32218) and Listeria monocytogenes (ATCC 19115), were used and mantein at $4^{\circ} \mathrm{C}$. They were inoculated in nutritive broth (BD Bioxon, Mexico) for $24 \mathrm{~h}$ at $37^{\circ} \mathrm{C}$.

In order to standardize the cultures to obtain a $10^{7} \mathrm{CFU} / \mathrm{mL}^{1}$, the bacteria were cultured in trypticase soy broth (BD Bioxon, Mexico) for $18 \mathrm{~h}$ at $37^{\circ} \mathrm{C}$. Using fresh broth, aliquots were taken until an absorbance of 0.05 at $600 \mathrm{~nm}$ was reached.

\section{Determination of Minimum inhibitory concentration (MIC)}

The microdilution assay method employed by Eloff (1998) was carried out to determine the minimum inhibitory concentration of the pepper extracts. A 96 well plate was used and $150 \mathrm{~mL}$ of previously prepared inoculums $\left(10^{7} \mathrm{CFU} / \mathrm{mL}\right)$ were placed in each well and then mixed with a known and variable volume of extract (100, 75, 50 and $25 \mu \mathrm{L}$ of each extract). Fresh trypticase soy broth was used to complete a volume of $250 \mathrm{~mL}$ and thoroughly mixed. The plate was incubated for at $37^{\circ} \mathrm{C}$ and after 24 h., $50 \mu \mathrm{L}$ of broth/extract solution were placed in Petri dish. Trypticase soy agar was poured in a dish and incubated at $37^{\circ} \mathrm{C}$ and. After overnight incubation colonies quantification was made.

The minimum inhibitory concentration values of each extract were obtained as the minimum concentration of antimicrobial (extract) that inhibited the growth of microorganisms used after proper incubation (Andrews 2001).

\section{Test for synergism}

Combination of two Capsicum antimicrobials were tested against the aforementioned strains by the checkerboard method according to Pillai \& Mcellering (2005). Concentration for both antimicrobials ranged from 50 to $300 \mu \mathrm{L} / \mathrm{mL}$; each combination was tested in duplicates. The minimum inhibitory (MIC) for each extract in every combination is the concentration in which the microorganism was inhibited and the fractional inhibitory concentration (FIC) was calculated using equations 6 and 7:

$$
\begin{aligned}
& \mathrm{FIC}_{\mathrm{a}}=\mathrm{MIC}_{\mathrm{a} / \text { combination }} / \mathrm{MIC}_{\mathrm{a} / \text { alone }} \\
& \mathrm{FIC}_{\mathrm{b}}=\mathrm{MIC}_{\mathrm{b} / \text { combination }} / \mathrm{MIC}_{\mathrm{b} / \text { alone }}
\end{aligned}
$$


To obtain the FIC for the whole combination or FIC index, the sum of the FIC values for each extract was calculated as follows (Equation 8):

$$
\mathrm{FIC}_{\text {index }}=\mathrm{FIC}_{\mathrm{a}}+\mathrm{FIC}_{\mathrm{b}}
$$

According to Braga et al. (2005), the results can be defined in terms of FIC index values as synergism $(\leq 0.5)$, additive $(>0.5$ and $\leq 4.0)$ and antagonism $(>4.0)$.

\section{Statistical analysis}

The data obtained was analyzed with Minitab v. 15 (Minitab Inc., USA) by ANOVA with a 95\% level of significance and with Tukey's comparison of means. A full factorial design of two factor; pepper (with two levels) and pepper part (with three levels) was applied to determine the influence of such factors into de Minimum Inhibitory Concentration (MIC) for each strain. Each experiment was conducted with three replicates and analyzed by an analysis of variance with a significance level of $95 \%$ with a general linear model.

\section{Results and discussion}

Capsaicinoids, carotenoids, total phenolic compounds and flavonoids determination

The data obtained for capsaicinoids, carotenoids, total phenolic compounds and flavonoids are presented in Table 1. 
Table 1. Composition of methanolic extracts from two pepper cultivars; Serrano (Capsicum annuum L. acuminatum) and Habanero (Capsicum chinense) peppers.

\begin{tabular}{|c|c|c|c|c|c|c|c|}
\hline & & & \multicolumn{4}{|c|}{ Carotenoids } & \multirow[b]{2}{*}{ Flavonoids } \\
\hline & Capsaicin & Total phenolics & Lycopene & b-carotene & $C R$ & $C Y$ & \\
\hline Pepper & mg $100 \mathrm{~g}^{-1}$ & mg $100 \mathrm{~g}^{-1} \mathrm{GAE}$ & $\mathrm{mg} \mathrm{kg}^{-1}$ & & & & $\mathrm{mg} \mathrm{kg}^{-1} \mathrm{QE}$ \\
\hline \multicolumn{8}{|l|}{ Serrano } \\
\hline Seed & $1.90 \pm 0.09^{\mathrm{a}, \mathrm{x}}$ & $46.25 \pm 10.20^{\mathrm{a}, \mathrm{x}}$ & $43.95 \pm 4.11^{\mathrm{a}, \mathrm{x}}$ & $11.72 \pm 2.13^{\mathrm{a}, \mathrm{x}}$ & $1.14 \pm 0.05^{\mathrm{a}, \mathrm{x}}$ & $0.18 \pm 0.01^{\mathrm{a}, \mathrm{x}}$ & $0.81 \pm 0.01^{\mathrm{a}, \mathrm{x}}$ \\
\hline Pericarp & $65.22 \pm 6.40^{\mathrm{b}, \mathrm{x}}$ & $144.18 \pm 14.30^{\mathrm{b}, \mathrm{x}}$ & $50.07 \pm 1.23^{\mathrm{b}, \mathrm{x}}$ & $40.53 \pm 4.81^{\mathrm{b}, \mathrm{x}}$ & $1.12 \pm 0.03^{\mathrm{a}, \mathrm{x}}$ & $0.32 \pm 0.02^{\mathrm{b}, \mathrm{x}}$ & $1.23 \pm 0.07^{\mathrm{b}, \mathrm{x}}$ \\
\hline $\begin{array}{c}\text { Whole } \\
\text { fruit }\end{array}$ & $323.32 \pm 15.70^{\mathrm{c}, \mathrm{x}}$ & $336.42 \pm 15.41^{\mathrm{c}, \mathrm{x}}$ & $42.37 \pm 3.6^{\mathrm{a}, \mathrm{x}}$ & $46.32 \pm 2.63^{b, x}$ & $1.11 \pm 0.03^{\mathrm{a}, \mathrm{x}}$ & $0.59 \pm 0.01^{\mathrm{c}, \mathrm{x}}$ & $1.44 \pm 0.12^{\mathrm{b}, \mathrm{x}}$ \\
\hline \multicolumn{8}{|l|}{ Habanero } \\
\hline Seed & $2.30+0.07^{\mathrm{a}, \mathrm{x}}$ & $3.18+0.20^{\mathrm{a}, \mathrm{y}}$ & $4.32+0.82_{\mathrm{a}, \mathrm{y}}$ & $2.01+0.13^{\mathrm{a}, \mathrm{y}}$ & $0.12+0.01^{\mathrm{a}, \mathrm{y}}$ & Traces & $0.11+0.05^{\mathrm{a}, \mathrm{y}}$ \\
\hline Pericarp & $63.70+9.61^{\mathrm{b}, \mathrm{x}}$ & $34.07+.06^{\mathrm{b}, \mathrm{y}}$ & $17.71+1.20^{\mathrm{b}, \mathrm{y}}$ & $105.22+20.34^{\mathrm{b}, \mathrm{y}}$ & $0.75+0.03^{\mathrm{b}, \mathrm{y}}$ & $0.61+0.02^{\mathrm{a}, \mathrm{y}}$ & $1.15+0.04^{\mathrm{a}, \mathrm{y}}$ \\
\hline $\begin{array}{c}\text { Whole } \\
\text { fruit }\end{array}$ & $742.50+20.12^{\mathrm{c}, \mathrm{y}}$ & $232.51+13.71^{\mathrm{c}, y}$ & $19.55+3.52^{\mathrm{b}, \mathrm{y}}$ & $102.03+11.89^{\mathrm{b}, \mathrm{y}}$ & $0.64+0.03^{\mathrm{b}, \mathrm{y}}$ & $0.70+0.07^{\mathrm{a}, \mathrm{y}}$ & $0.26+0.9^{\mathrm{a}, \mathrm{y}}$ \\
\hline
\end{tabular}

Fuente: Elaboración propia

Capsaicin content was significantly higher in Habanero pepper (ranging from 2.30 to

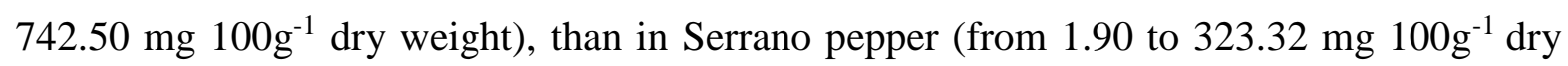
weight). This probably because Habanero pepper (Capsicum chinense) is considered as one of the hottest pepper in the world. Also, it was observed that whole pepper fruit were significantly higher $(\mathrm{p}<0.05)$ in capsaicin levels than in both seed and pericarp. This result is related to pepper parts were cleaned out from placental tissue; Broderick \& Cooke (2009), stated that vesicles are responsible for the storage of capsaicin, which are present in plancental tissue.

Total phenolic content was higher in pepper seeds (34.07 and $144.18 \mathrm{mg}$ galic acid equivalents $100 \mathrm{~g}^{-1}$ ) than pepper pericarp (ranged from 3.18 to $46.25 \mathrm{mg}$ galic acid $100 \mathrm{~g}^{-1}$ ), with a significant difference $(\mathrm{p}<0.05)$. These results were in agreement with those obtained by Singh et al. (2008), who observed that phenolic contents, such as tannic, ferulic and cinnamic acids, were higher in seeds than in pulp of green and red peppers (Capsicum annum). Also, it was observed that amounts of phenolic compounds in Serrano pepper (from 
46.25 to $336.42 \mathrm{mg}$ of galic acid $100 \mathrm{mg}^{-1}$ ) were higher than in Habanero pepper (from 3.18 to $232.51 \mathrm{mg}$ of galic acid $100 \mathrm{~g}^{-1}$ ). Hassimotto et al. (2005), found similar results where concentrations of phenolic compounds were significantly different between green and red peppers and the concentrations ranged from 1860 to $11220 \mathrm{mg} \mathrm{kg}^{-1}$ ). However, Reis et al. (2013) found that in a Brazilian cultivar of Capsicum chinense concentrations of phenolic compounds were as high as $9000 \mathrm{mg} \mathrm{GAE} 100 \mathrm{~g}^{-1}$, being these in disagreement with the results presented above.

Carotenoid content (particularly b-carotene) were significantly higher $(\mathrm{p}<0.05)$ in Habanero pepper than in Serrano pepper. The aforementioned difference in $\beta$-carotenes (red, orange and yellow pigments) could possibly be due to the ripening stage (the ripening stage was chosen in an aleatory manner) of each cultivar used in this research. In a research by Wall et al. (2001), in which they compared the concentration of bioactive compounds (included carotenoids and $\beta$-carotene) of several pepper cultivars, found that Habanero pepper had a significantly higher amount of $\beta$-carotene than other cultivars, such as Serrano.

Both red and yellow fractions were different for the two cultivars studied. Serrano presented a red fraction (from 1.11 to $1.14 \mathrm{mg} \mathrm{Kg}^{-1}$ ) higher than yellow (ranged from 0.18 to $0.59 \mathrm{mg} \mathrm{Kg}^{-1}$ ) probably because it possesses an elevated amount of capsanthin and capsorubin. On the other hand, Habanero pepper contains similar quantities of both red and yellow fraction (from 0.12 to $0.75 \mathrm{mg} \mathrm{Kg}^{-1}$ and from traces to $0.70 \mathrm{mg} \mathrm{Kg}^{-1}$ for red and yellow fractions respectively), these results could probably be due to its similar content of capsanthin, capsorubin (red fraction) and zeasanthin, $\beta$-cryptoxanthin and b-carotene (yellow fraction) (Hornero-Méndez \& Mínguez-Mosquera, 2001). The same could also explain the significantly higher quantity $(\mathrm{p}<0.05)$ of red fractions for Serrano pepper and the raised levels of the yellow fraction for Habanero than for Serrano pepper.

Regarding flavonoids content, Serrano pepper own a significantly $(\mathrm{p}<0.05)$ higher levels (0.81-1.44 mg Kg-1) than Habanero (0.11-0.26 $\mathrm{mg} \mathrm{Kg}^{-1}$ ). Serrano was in the range of the data obtained by Marinova et al. (2005) were their values were from 4.1 to $27.4 \mathrm{mg} 100 \mathrm{~g}^{-1}$ fresh weight. Butcher et al. (2013) observed and concluded that Habanero cultivars possess low quantities of flavonoids which was also what it was found in the present research comparing it with Serrano pepper. Also, as stablished by several research works, flavonoids 
and other bioactive compounds depend on cultivation, ripeness, storage and other factors (Zhang \& Hamauzu, 2003; Marinova et al., 2005; Navarro et al., 2006).

\section{Antioxidant capacity determination}

Antioxidant activity as Total Antioxidant Capacity (TAC) for both pepper cultivars is shown in Table 2.

Table 2. Antioxidant activity and percentage of inhibition of extracts obtained from Serrano (Capsicum annuum L. acuminatum) and Habanero (Capsicum chinense) peppers

\begin{tabular}{|c|c|c|}
\hline & $\%$ inhibition & $\mu \mathrm{g}$ Trolox $100 \mathrm{~g}^{-1} \mathrm{DW}$ \\
\hline \multicolumn{3}{|l|}{ Serrano } \\
\hline Seed & $89.06+1.56^{\mathrm{a}, \mathrm{x}}$ & $185.04+9.65^{\mathrm{a}, \mathrm{x}}$ \\
\hline Pericarp & $82.61+2.15^{b, x}$ & $168.47+10.54^{\mathrm{b}, \mathrm{x}}$ \\
\hline Whole fruit & $81.81+0.98^{b, x}$ & $166.43+13.61^{\mathrm{b}, \mathrm{x}}$ \\
\hline \multicolumn{3}{|l|}{ Habanero } \\
\hline Seed & $91.37+1.78^{\mathrm{a}, \mathrm{x}}$ & $190.99+15.32^{\mathrm{a}, \mathrm{x}}$ \\
\hline Pericarp & $77.95+2.45^{\mathrm{b}, \mathrm{x}}$ & $156.50+13.74^{\mathrm{b}, \mathrm{y}}$ \\
\hline Whole fruit & $79.71+2.78^{\mathrm{b}, \mathrm{x}}$ & $161.02+12.61^{\mathrm{b}, \mathrm{x}}$ \\
\hline \multicolumn{3}{|c|}{$\begin{array}{l}\text { a-c Same letter show no significative difference among pepper parts } \\
\text { x-y Same letter show no significative difference among pepper } \\
\text { species }\end{array}$} \\
\hline
\end{tabular}

From the data obtained from TAC values, there was no significant difference ( $p>0.05$ ) between the cultivars studied; although there was evidence that showed that both cultivars are significantly different regarding to its composition, combinations of all bioactive components could have similar antioxidant capacity. The latter is in agreement with the research made by Howard et al. (2000) were they compared different pepper cultivars and observed similar antioxidant capacity.

However, there is a significant difference in the antioxidant capacity obtained from the seed (185.04 mg Trolox $100 \mathrm{~g}^{-1} \mathrm{dw}$. For Serrano seeds and $91.37 \mathrm{mg}$ Trolox $100 \mathrm{~g}^{-1} \mathrm{dw}$ for Habanero seeds) alone than from the other parts. It could be seen in previous work by Singh et al. (2008) that seed possesses great amounts of tannic acid (ranged from 50.97 to $105.79 \mu \mathrm{g} \mathrm{g}^{-1}$ fresh weight), ferulic acid (from 0.27 to $0.29 \mu \mathrm{g} \mathrm{g} \mathrm{g}^{-1}$ fresh weight) and 
cinnamic acid (from 0.12 to $055 \mu \mathrm{g} / \mathrm{g}$ fresh weight). It is worth mentioned that these acids were no found in other pepper parts.

\section{Determination of minimum inhibitory concentration}

Minimum inhibitory concentration values are display in Table 3.

Table 3. Values of Minimum inhibitory concentration of two pepper cultivars; Serrano (Capsicum annuum L. acuminatum) and Habanero (Capsicum chinense) against Escherichia coli and Listeria monocytogenes.

\begin{tabular}{|c|c|c|}
\hline & Escherichia coli & Listeria monocytogenes \\
\hline & & mg $^{-1}$ \\
\hline Serrano & & $0.15+0.01^{\mathrm{a}, \mathrm{x}}$ \\
\hline Seed & $0.34+0.03^{\mathrm{a}, \mathrm{x}}$ & $0.10+0.01^{\mathrm{b}, \mathrm{x}}$ \\
\hline Pericarp & $0.26+0.05^{\mathrm{b}, \mathrm{x}}$ & $0.11+0.01^{\mathrm{b}, \mathrm{x}}$ \\
\hline Whole fruit & $0.13+0.01^{\mathrm{c}, \mathrm{x}}$ & $0.14+0.01^{\mathrm{a}, \mathrm{x}}$ \\
\hline Habanero & & $0.08+0.01^{\mathrm{b}, \mathrm{y}}$ \\
\hline Seed & $0.15+0.01^{\mathrm{a}, \mathrm{y}}$ & $0.11+0.01^{\mathrm{c}, \mathrm{y}}$ \\
\hline Pericarp & $0.13+0.01^{\mathrm{a}, \mathrm{y}}$ & \\
\hline Whole fruit & $0.08+0.01^{\mathrm{c}, \mathrm{y}}$ & \multicolumn{2}{|c|}{} \\
\hline
\end{tabular}

L. monocytogenes was significantly more sensitive than E. coli $(\mathrm{p}<0.05)$. This sensitivity was probably due to the large quantities of acids present in pepper extracts decreasing $\mathrm{pH}$ growth media, and it was previously established that L. monocytogenes growth at a pH between 4.4 and 9.4 (Marzocca et al., 2004).

Soumaya \& Nair (2012) found higher MIC values against fungi species (ranged from 1.25 to $10 \mathrm{mg} \mathrm{mL}^{-1}$ ), which are morphologically different than bacterial strains. The results presented in this paper disagree with the ones obtained by Salih (2006) were they showed, in oil extracts, a minimum inhibitory concentration of $2.5 \mu \mathrm{g} \mathrm{mL}^{-1}$ for E. coli and $5 \mu \mathrm{g} \mathrm{mL}^{-1}$ for L. monocytogenes, both being lower than the concentrations needed in this study. 


\section{Test for synergism}

Based on the FIC index calculations (Table 4), only the combinations of Serrano seed/Habanero seed and Serrano whole fruit/Habanero pericarp show an additive effect against Escherichia coli with a FIC index value greater than 0.5 (0.55 and 1.044 respectively). Synergistic effects of the other seven combinations against the same bacteria are observed with a FIC index less than 0.5. These results can be attributed to the combination of bioactive compounds in both pepper species such as ortho-coumaric acid, capsaicin (present in Habanero pepper), meta-coumaric acid, ortho coumaric acid, transcinnamic acid, capsaicin and dihydrocapsaicin (present in Serrano pepper) (Acero-Ortega et al., 2003). Although there are few research works using Capsicum extracts in combination with another natural extracts (Morre and Morre, 2007; Lillehoj et al., 2011: Ilsley et al., 2002) in a study made by Gutierrez et al. (2009) they observed a synergistic and additive effects when two types of essential oils were combined (oregano, thyme, lemon and marjoram) against bacterial strains like Enterobacter spp., Listeria spp., Lactobacillus spp. and Pseudoman spp.

Table 4. Values of Fractional inhibitory concentration index of two pepper cultivars; Serrano (Capsicum annuum L. acuminatum) and Habanero (Capsicum chinense) against Escherichia coli and Listeria monocytogenes.

\begin{tabular}{|c|c|c|}
\hline & \multicolumn{2}{|c|}{ FIC index } \\
\hline & Escherichia coli & Listeria monocytogenes \\
\hline S.P X H.P & 0.23 & 0.56 \\
\hline S.P X H.S & 0.38 & 1.04 \\
\hline S.P X H.WF & 0.21 & 0.37 \\
\hline S.S X H.P & 0.34 & 0.82 \\
\hline S.S X H.S. & 0.55 & 0.69 \\
\hline S.S X H.WF & 0.31 & 0.45 \\
\hline S.WF X H.P & 1.04 & 0.43 \\
\hline S.WF X H.S & 0.44 & 1.05 \\
\hline $\begin{array}{c}\text { S.WF X } \\
\text { H.WF }\end{array}$ & 0.27 & 0.22 \\
\hline $\begin{array}{l}\text { S.P. Serrano pe } \\
\text { H.S. Habanero } \\
\text { fruit. }\end{array}$ & $\begin{array}{l}\text {, S.S. Serrano se } \\
\text { H.P. Habanero pe }\end{array}$ & $\begin{array}{l}\text { F. Serrano whole fruit, } \\
\text { H.WF. Habanero whole }\end{array}$ \\
\hline
\end{tabular}

Fuente: Elaboración propia 
In the same way, a synergistic effect against Listeria monocytogenes was observed when combined extracts obtained from Serrano pericarp/Habanero whole fruit; Serrano seed/ Habanero whole fruit; Serrano whole fruit/Habanero pericarp and Serrano whole fruit/Habanero whole fruit with FIC index values less than 0.5. An additive effect was found in the other combinations. Also Acero-Ortega et al. (2003), combined bioactive compounds of three pepper species (Habanero, Serrano and Bell peppers) and found that when they combined compounds from Serrano and Habanero peppers a synergistic effect was observed against Erwinia carotovora the latter is in agreement with the results observed in the present study.

\section{Conclusions}

Control of Escherichia coli and Listeria monocytogenes must be done in order to reduce the risk of food related outbreaks causing enterogastric diseases. Composition of the two Capsicum species studied in the present research depends upon the specie and the part studied. It was also proved that Capsicum extracts could be a useful way to inhibit growth of the aforementioned bacterial species. There were also synergistic and additive effects when two Capsicum extracts were combined, which resulted in improvement to the inhibitory effect of these extracts. These combinations could be used as a good alternative to food safety and food preservation and its applicability must be studied. 


\section{Bibliography}

Acero-Ortega, C., Dorantes-Alvarez, L., Jaramillo-Flores, M.E., \& Hernández-Sánchez, H. (2003) Effect of chilli (Capsicum anuum L.) extracts and derived compounds on growth of Erwinia carotovora subsp. Carotovora (Jones). Revista Mexicana de Fitopatología, 21(2), 233-237. Retrieve from http://www.redalyc.org/articulo.oa?id=61221220

Aminifard, M.H., Aroiee, H., Nemati, H., Azizi, M., \& Jaafar, H.Z.E. (2012) Fluvic Acid affects pepper antioxidant activity and fruit quality. African Journal of Biotechnology, 11(68), 13179-13185. Retrieve from http://www.academicjournals.org/journal/AJB/article-abstract/72526EF32280

Andrews, J.M. (2001) Determination of minimun inhibitory concentrations. Journal of Antimicrobial Chemotherapy, 48(S1), 5-16. Retrieve from http://jac.oxfordjournals.org/content/48/suppl_1/5.abstract

Braga, L.C., Leite, A.A.M., Xavier, K.G.S., Takahashi, J.A., Bemquerer, M.P., CharloneSouza,E., \& Nascimento, A.M.A. (2005) Synergic interaction between pomegranate extract and antibiotics against Staphylococcus aureus. Canadian Journal of Microbiology, 51, 541-547. Retrieve from http://www.ncbi.nlm.nih.gov/pubmed/16175202

Broderick, C.E. \& Cooke, P.H. (2009) Fruit Composition, tissues and localization of antioxidants and capsaicinoids in Capsicum peppers by fluorescens microscopy. Acta Horticulturae, 841, 85-90. Retrieve from http://www.actahort.org/books/841/841_7.htm

Buchanan, R.L. \& Doyle, M.P. (1997). Foodborne disease significance of Escherichia coli O157:H7 and other enterohemorrhagic E. coli. Food Technology, 51(10), 69-76. Retrieve from http://www.ift.org/knowledge-center/read-ift-publications/sciencereports/scientific-status-summaries/foodborne-disease-significance-of-escherichia$\underline{\text { coli.aspx }}$

Butcher, J.D., Crosby, K.M., Yoo, K.S., Patil, B.S., Ibrahim, A.M.H., Leskovar, D.I. \& Jifon, J.L. (2012). Environmental and genotypic variation of capsaicinoid and flavonoid concentrations in Habanero (Capsicum chinense)peppers. Horticultural 
Science,

47,

574-579.

Retrieve

from

http://hortsci.ashspublications.org/content/47/5/574.full

Centers for Disease Control and Prevention (CDC). (2013). Tracking and reporting $\begin{array}{llll}\text { foodborne } & \text { disease } & \text { outbreaks. } & \text { Retrieve }\end{array}$ http://www.cdc.gov/features/dsfoodborneoutbreaks/.

Cichewicz, R.H. \& Thorpe, P.A.E. (1996). The antimicrobial properties of chili peppers (Capsicum species) and their used in Mayan medicine. Journal of $\begin{array}{llll}\text { Ethnopharmacology, } & 52(2), & \text { 61-70. } & \text { Rretrieve }\end{array}$ http://www.ncbi.nlm.nih.gov/pubmed/8735449

Dorantes, L., Colmenero, R., Hernández, H., Mota, L., Jaramillo, M.E., Fernández, E., \& Solano, C. (2000) Inhibition of growth of some foodborne pathogenic bacteria by Capsicum annum L. extracts. International Journal of Food Microbiology, 57, 125128.

Retrieve

from http://www.researchgate.net/publication/223228175_Inhibition_of_growth_of_some _foodborne_pathogenic_bacteria_by_Capsicum_annum_extracts._Int_J_Food_Micro biol_57(1-2)125-128

Eloff, J.N. (1998) A sensitive and quick microplate method to determine the minimal inhibitory concentration oh plant extracts for bacteria. Planta medica, 64, 711-713. Retrieve from http://www.ncbi.nlm.nih.gov/pubmed/9933989

Farber, J.M. \& Peterkin, P. (1991). Listeria monocytogenes, a food-borne pathogen. Microbiological Reviews, 55(3), 476-511. Retrieve from http://www.ncbi.nlm.nih.gov/pubmed/1943998

Gibbs, H.A.A. \& O’Garro, L.W. (2004). Capsaicin content of West Indies Hot pepper cultivars using colorimetric and Chromatographic Techniques. HortScience. 39(1):132-135.

Gutierrez, J., Barry-Ryan, C., \& Bourke, P. (2009). Antimicrobial activity of plant essential oils using food model media: efficacy, synergistic potential, and interaction with food components. Food Microbiology, 26(2), 142-150. Retrieve from http://www.sciencedirect.com/science/article/pii/S0740002008001986 
Hassimotto, N.M.A., Genovese, M.I. \& Lajolo, F.M. (2005). Antioxidant activity of dietary fruits, vegetables, and commercial frozen fruit pulps. Journal of Agricultural and Food Chemistry, 53, 2928-2935. Retrieve from http://www.ncbi.nlm.nih.gov/pubmed/15826041

Hornero-Méndez, D. \& Mínguez-Mosquera, M.I. (2001). Rapid spectrophotometric determination of red and yellow isochromic carotenoid fractions in paprika and red pepper oleoresins. Journal of Agricultural and Food Chemistry, 49, 3584-3588. Retrieve from http://www.ncbi.nlm.nih.gov/pubmed/11513632

Howard, L.R., Talcott, S.T., Brenes, C.H. \& Villalon, B. (2000). Changes in phytochemical and antioxidant activity of selected pepper cultivars (Capsicum species) as influenced by maturity. Journal of Agricultural and Food Chemistry, 48, 1713-1720. Retrieve from http://www.ncbi.nlm.nih.gov/pubmed/11513632

Ilsley, S., Miller, H., Greathead, H. \& Kamel, C. (2002). Herbal sow diets boost preweaning growth. Feed Mix, 10(3), 24-25. Retrieve from http://proda.pigprogress.net/PageFiles/22386/001_boerderij-downloadPP5461D01.pdf

Lillehoj, H.S., Kim, K.K., Bravo, D.M. \& Lee, S.H. (2011). Effect of dietary plant -derive phytonutrients on the genome-wide profiles and coccidiosis resistance in the broiler chickens. BMC Proceedings, 5(4), S34. Retrieve from http://www.biomedcentral.com/1753-6561/5/S4/S34

Marinova, D., Ribarova, F. \& Atanassova, M. (2005). Total phenolics and total flavonoids in Bulgarian fruits and vegetables. Journal of the University of Chemical Technology and Metallurgy, 40, 255-260. Retrieve from http://www.researchgate.net/publication/258769164_Total_phenolics_and_flavonoid $\underline{\text { s_in Bulgarian fruits and vegetables }}$

Martínez, J.L. \& Baquero, F. (2000) Mutation frequencies and antibiotic resistance. Antimicrobial Agents Chemotherapy, 44(7), 1771-1777. Retrieve from http://www.ncbi.nlm.nih.gov/pubmed/10858329

Marzocca, M., Marucci, P., Sica, M. \& Alvarez, E. (2004). Detección de Listeria monocytogenes en distintos productos alimenticios y en muestras de ambientes de 
una amplia cadena de supermercados de la ciudad de Bahía Blanca, Argentina. Revista Argentina de Microbiología, 36, 179-181. Retrieve from http://www.scielo.org.ar/scielo.php?script=sci_arttext\&pid=S0325$\underline{75412004000400006}$

Morre, J.D. \& Morre, D.M. (2007). Composition and methods based on synergies between Capsicum extracts and tea cathechins for prevention and treatment of cancer. U.S. Patent 7192612B2.

Nagata, M., \& Yamashita, I. (1992) Simple method for simultaneous determination of chlorophyll and carotenoids in tomato fruit. Nippon Shokuhin Kogyo Gakkaish, 39(10), 925-928. Retrieve from http://cse.naro.affrc.go.jp/mnagata/pigment2.pdf

Navarro, J.M., Flores, P., Garrido, C. \& Martínez, V. (2006). Changes in the contents of antioxidant compounds in pepper fruits at different ripening stages, as affected by salinity. Food Chemistry, 96, 66-73. Retrieve from http://www.sciencedirect.com/science/article/pii/S0308814605001585

Odds, F.C. (2003) Synergy, antagonism, and what the chequerboard puts between them. Journal of Antimicrobial Chemotherapy, 52, 1. Retrieve From http://jac.oxfordjournals.org/content/52/1/1.full

Ornelas-Paz, J.J., Martínez-Burruola, J.M., Ruíz-Cruz, S., Santana-Rodriguez, V., IbarraJunquera, V., Olivas, G.I., \& Perez-Martínez, D. (2010) Effect of cooking on the capsaicinoids and phenolics contents of Mexican peppers. Food Chemistry, 119, 1619-1625.

Retrieve

from http://www.sciencedirect.com/science/article/pii/S0308814609011145

Pillai, S.K., Moellering, R.C., \& Eliopoulos, G.M. (2005) Antimicrobial Combinations in Antibiotics. In V. Lorian (Ed.), Laboratory Medicine (pp. 365-440). Philadelphia: Lippincott Williams, Wilkins.

Re, R., Pellegrini, N., Proteggente, A., Panala, A., Yang, M., \& Rice-Evans, C. (1999) Antioxidant activity applying and improved ABTS radical cation decolorization assay. Free Radical \& Medicine, 26, 1231-1237. Retrieve from http://www.ncbi.nlm.nih.gov/pubmed/10381194 
Reis, R.C., Castro, V.C., Devilla, I.A., Oliveira, C.A., Barbosa, L.S. \& Rodovalho, R. (2013). Effect of drying temperature on the nutritional and antioxidant qualities of cumari peppers from Pará (Capsicum chinense Jacqui.). Brazilian Journal of Chemical Engineering, 30(2), 337-343. Retrieve from http://www.scielo.br/pdf/bjce/v30n2/v30n2a11.pdf

Rodriguez-Angeles, M.G. (2002). Principales características y diagnóstico de los grupos patógenos de Escherichia coli. Salud Pública de México, 44(5), 464-475. Retrieve from http://bvs.insp.mx/rsp/articulos/articulo.php?id=000363

Salih, A.A. (2006). Extraction and identification of oil extract from Capsicum annuum L. fruits and study of its antimicrobial activity. Journal of Basrah Researches, 32(3), 80-87. Retrieve from http://www.iasj.net/iasj?func=fulltext\&aId=57971

Singh, U., Suman, A., Sharma, M., Singh, J., Singh, A. \& Maurya, S. (2008). HPLC analysis of the phenolic profiles in different part s of chilli (Capsicum annum) and Okra (Abelmoschus esculentus L.) Moench. The internet Journal of Alternative Medicine, 5(2). Retrieve from http://ispub.com/IJAM/5/2/7183

Soumaya, S.L. \& Nair, B.R. (2012). Antifungal efficacy of Capsicum frutescens L. extracts against some prevalent fungal strain associated width groundnut storage. Journal of Agricultural Technology, 8(2), 739-750. Retrieve from http://www.ijataatsea.com/pdf/v8_n2_12_March/29_IJAT\%202012_8_2__S.L.pdf

Wall, M.M., Wadell, C.A. \& Bosland, P.W. (2001). Variation In b-carotene and total carotenoid content in fruits of Capsicum. Horticultural Science, 36(4), 746-749. Retrieve from http://hortsci.ashspublications.org/content/36/4/746.full.pdf

Yoo, K.M., Lee, C.H., Lee, H., Moon, B.K. \& Lee, C.Y. (2008). Relative antioxidant and cytoprotective activities of common herbs. Journal of Food Chemistry, 106, 929: 936.

Retrieve

from http://www.sciencedirect.com/science/article/pii/S0308814607006814

Zhang, D. \& Hamauzu, Y. (2003). Phenolic compounds, ascorbic acid, carotenoids and antioxidant properties of green, red and yellow bell pepper. Food, Agriculture and $\begin{array}{llll}\text { Environment, } & 2, & 22-27 . & \text { Retrieve }\end{array}$ http://www.researchgate.net/publication/228643773_Phenolic_compounds_ascorbic 
_acid_carotenoids_and_antioxidant_properties_of_green_red_and_yellow_bell_pepp $\underline{\text { ers }}$

Zimmer, A.R., Leonardi, B., Miron, D., Schapoval, E., Oliveira, J.R., \& Grosman, G. (2012). Antioxidant and antiinflamatory properties of Capsicum baccatum: from traditional use to scientific approach. Journal of Ethnopharmacology, 139(1), 228233. Retrieve from http://www.ncbi.nlm.nih.gov/pubmed/22100562 